\title{
PENDIDIKAN KONSERVASI BADAK SUMATRA DAN JAWA PADA PESERTA DIDIK SEKOLAH MENENGAH KEJURUAN NEGERI 3 PANDEGLANG, PROVINSI BANTEN
}

\author{
Bainah Sari Dewi ${ }^{1}$, Sugeng P. Harianto ${ }^{1}$, Gunardi D. Winarno ${ }^{1}$, Yulia Rahma Fitriana ${ }^{1}$, \\ Nur Arif Rohman ${ }^{2}$, Mochamad Syamsudin ${ }^{3}$ \\ ${ }^{1}$ Dosen Program Studi Magister Kehutanan, Fakultas Pertanian, Universitas Lampung \\ ${ }^{2}$ Mahasiswa Program Studi Magister Kehutanan, Fakultas Pertanian, Universitas Lampung \\ Jl. Prof. Sumantri Brojonegoro No.1 Bandar Lampung 35145 \\ ${ }^{3}$ Balai Taman Nasional Ujung Kulon, Pandeglang Banten \\ Jl. Perintis Kemerdekaan No. 51 Kec. Labuan Kab. Pandeglang 42264 \\ Penulis Korespodensi : bainah.saridewi@fp.unila.ac.id
}

\begin{abstract}
Abstrak
Sumberdaya hutan di Indonesia sebagai bagian dari Megabiodiversity Country perlu dikonservasi. Pengabdian Kepada Masyarakat adalah bagian dari Tridarma Perguruan Tinggi dalam memanfaatkan Ilmu Pengetahuan dan Teknologi untuk memajukan kesejahteraan masyarakat dan mencerdaskan kehidupan bangsa. Pendididikan Konservasi merupakan kegiatan pengabdian masyarakat untuk pengupayaan perlindungan, pemanfaatan dan pengawetan sumberdaya hutan dalam kepentingan generasi sekarang ke generasi masa datang. Pengupayaan kegiatan konservasi dilakukan di habitat asli maupun bukan aslinya, seperti halnya konservasi Badak yang ada di Taman Nasional. Tim Konservasi Universitas Lampung, Magister Kehutanan Fakultas Pertanian Universitas Lampung, Peer Group KSDH, Jurusan Kehutanan Fakultas Pertanian Universitas Lampung, Himasylva, Persatuan Sarjana Kehutanan Indonesia DPD Lampung, Balai Taman Nasional Ujung Kulon (TNUK) dan SMK Negeri 3 Pandeglang Provinsi Banten memiliki upaya melaksanakan Pendidikan Konservasi untuk pelestarian konservasi Badak Sumatra dan Badak Jawa yang dilindungi ini. Kegiatan pendidikan konservasi dilakukan pada bulan Mei hingga Juni 2021 dan puncak pelaksanaan pada hari Senin tanggal 14 Juni 2021 dengan metode pengabdiannya berupa ceramah, diskusi dan tanya jawab serta lomba poster. Peningkatan pemahaman peserta naik sebesar 35\%. Presentase kenaikan dinilai sangat baik, karena semangat yang tinggi dari peserta dalam mengikuti kegiatan pendidikan konservasi dalam meningkatkan pemahaman tentang konsep konservasi dan pentingnya konservasi Badak Sumatra dan Badak Jawa tercapai.
\end{abstract}

Kata kunci: Badak Jawa, Badak Sumatra, Pendidikan Konservasi

\section{Pendahuluan}

Hutan Indonesia adalah negara yang kaya raya akan keanekaragaman hayati, di didalamnya terdapat banyak macam biodiversitas. Menurut Rohman dan Wulandari (2021), hutan Indonesia tidak asing jika dikatakan sebagai Megabiodiversity Country. Hal demikian juga telah disebutkan oleh Collin dan Dixon (1991), bahwa Indonesia adalah rumah bagi ribuan jenis keanekaragaman spesies dengan daratan Indonesia hanya mencapai 1,3\% daratan bumi, sementara di Indonesia terdapat 10\% tumbuhan dunia, $12 \%$ diantaranya mamalia, $16 \%$ adalah reptile dan amfibi serta $17 \%$ bagian dari burung. Menurut Mongabay Indonesia (2020), menyebutkan bahwa Indonesia adalah negara dengan wilayah hutan hujan tropis ketiga terluas setelah hutan hujan tropis di Brasil dan Republik Demokratik Kongo.

Pengabdian Kepada Masyarakat (PKM) adalah bagian dari Tridarma Perguruan Tinggi dalam kegiatan civitas akademika yang memanfaatkan Ilmu Pengetahuan dan Teknologi untuk memajukan kesejahteraan masyarakat dan mencerdaskan kehidupan bangsa (UU No. 12 Tahun 2012, Pasal 1 Ayat 9), salah satunya dengan kegiatan Pendidikan konservasi sumberdaya hutan. Sementara pendidikan konservasi adalah bagian dari pengupayaan kegiatan konservasi yang dapat 
dilakukan di habitat asli maupun di habitat bukan aslinya, seperti halnya konservasi Badak yang ada di Taman Nasional.

Menurut (WWF, 2020), menjelaskan bahwa keberadaan hutan di dunia mengalami banyak ancaman untuk keberadaannya, khususnya dari kegiatan manusia dan tekanan populasi penduduk dunia yang terus bertambah. Hal demikian perlu konsep konservasi sumberdaya hutan yang tentu harus diaplikasikan dalam pengelolaan sumber daya yang sangat penting tersebut. Diharapkan dengan penerapan konsep konservasi sumberdaya hutan, keanekaragaman ekosistem sampai dengan keanekaragaman spesies bisa dinikmati tidak hanya pada generasi sekarang, tetapi juga untuk generasi yang akan datang. Oleh karena itu kegiatan pengabdian kepada masyarakat ini dapat memberikan manfaat dalam menumbuhkan kepedulian terhadap Peserta Didik SMK Negeri 3 Pandeglang Provinsi Banten untuk lebih perduli dengan alam dan lingkungannya agar tetap lestari sebagai bentuk dari pemahaman terkait pentingnya konservasi sumberdaya hutan khususnya konservasi Badak Sumatra dan Badak Jawa. Begitu juga tujuan kegiatan Pendidikan konservasi ini adalah untuk memperkenalkan konsep konservasi dan pentingnya konservasi Badak Sumatra dan Badak Jawa pada Peserta Didik SMK Negeri 3 Pandeglang Provinsi Banten.

\section{Metode Kegiatan}

Kegiatan pendidikan konservasi ini dilakukan pada bulan Mei hingga Juni 2021 dan puncak pelaksanaan pada hari Senin tanggal 14 Juni 2021 dengan metode pengabdiannya berupa ceramah, diskusi dan tanya jawab serta lomba poster.

\section{A. Khalayak Sasaran Kegiatan}

Saasaran kegiatan Pengabdian Kepada Masyarakat ini adalah:

1. Peserta Didik Sekolah Menengah Kejuruan Negeri 3 Pandeglang Provinsi Banten, kelas XI dan X Bidang Keahlian Kehutanan yang berjumlah 136 siswa.

2. Peserta Didik Bidang Keahlian Kehutanan dari SMK yang terkait di Provinsi Banten dan Luar Banten.

3. Para guru pengajar Bidang Keahlian Kehutanan di SMKN 3 Pandeglang yang berjumlah 6 orang.

4. Musyawarah Guru Mata Pelajaran Bidang Keahlian Kehutanan Seluruh Indonesia.
5. Mahasiswa Jurusan Kehutanan, Fakultas Pertanian, Universitas Lampung yang berguna untuk menambah pengetahuan mengenai topik dan tema kegiatan.

6. Instansi terkait.

\section{B. Langkah-Langkah Kegiatan} tahapan:

Kegiatan ini dilakukan dalam beberapa

1. Persiapan dan koodinasi antara tim pengabdian dengan pihak SMKN 3 Pandeglang dengan menggunakan Whatsapp Group. Mahasiswa juga telah dilibatkan sejak tahapan ini.

2. Persiapan administratif oleh Tim Pengabdian di internal Universitas Lampung untuk melengkapi admistrasi kegiatan yang mencakup pembuatan surat tugas, finalisasi proposal dan laporan.

3. Persiapan teknis Tim Pengabdian yang menyiapkan keperluan teknis pelaksanaan pengabdian dengan memperiapkan link zoom, finalisasi pre-test dan post-test, dan beberapa kali rapat koordinasi kegiatan.

4. Penyampaian materi melalui Zoom dan Youtube.

5. Pembagian e-sertifikat kepada seluruh peserta, narasumber, panitia, dan para guru.

\section{Hasil dan Pembahasan Kegiatan}

A. Konsep dan Pentingnya Konservasi Badak Sumatra dan Jawa

Penyampaian konsep dan pentingnya konservasi Badak Sumatra dan Badak Jawa dalam kegiatan pendidikan konservasi ini telah disosialisasikan kepada Peserta Didik Sekolah Menengah Kejuruan Negeri 3 Pandeglang Provinsi Banten dengan harapan generasi muda mendatang di sekolah tersebut dapat memahami pentingnya konservasi sumberdaya hutan khususnya konservasi Badak Sumatra dan Badak Jawa yang telah diikuti sebanyak 300 peserta dengan perincian jumlah peserta dapat dilihat pada Tabel 1.

Berdasarkan pada tabel 1 diatas, menjelaskan bahwa jumlah peserta dari SMKN 3 Pandeglang sebanyak 142 peserta yang terdiri dari 136 peserta dari kelas X dan XI Bidang Keahlian Kehutanan dan 6 peserta dari Guru Produktif Bidang Keahlian 
Kehutanan. Sementara peserta dari Universitas Lampung sebanyak 85 peserta yang terdiri dari mahasiswa S1 dan S2 serta para Dosen Universitas Lampung. Demikian pula peserta dari instansi lain sebanyak 73 peserta, baik dari perguruan tinggi, SMK/SMA, dan instansi terkait. Kegiatan sosialisasi Pendidikan konservasi tentang pentingnya pelestarian konservasi Badak Sumatra dan Badak Jawa memberikan gambaran yang lebih mendalam bagi para generasi muda, khususnya Peserta Didik SMK Negeri 3 Pandeglang Provinsi Banten dalam menjaga dan melestarikan alam dan lingkungan. Hal demikian telah dijelaskan oleh Purmadi, et al. (2020), pendidikan berbasis konservasi dianggap penting dengan sistem pembelajaran yang bertujuan untuk menumbuhkan kesadaran dalam menjaga lingkungan serta keanekaragaman makhluk hidup agar tidak mengalami kepunahan, seperti pentingnya pelestarian konservasi Badak Sumatra dan Badak Jawa.

Tabel 1. Rincian jumlah peserta Pendidikan konservasi

\begin{tabular}{lc}
\hline Instansi Asal & Jumlah \\
\hline SMKN 3 Pandeglang & 142 \\
Universitas Lampung & 85 \\
Lain-lain & 73 \\
\hline Total & 300 \\
\hline
\end{tabular}

Konservasi sumber daya alam merupakan konsep yang penting untuk pengelolaan sumber daya alam, baik biotik maupun abiotik. Pengaturan mengenai konservasi sumberdaya hutan diatur oleh Undang-Undang Nomor 41 tahun 1999 tentang Kehutanan dan Undang-Undang Nomor 5 tahun 1990 tentang Konservasi Sumberdaya Hutan. Tiga Aspek Konservasi yaitu meliputi: (1) perlindungan, (2) pengawetan flora danfauna, dan (3) pemanfaatan secara lestari. Upaya konservasi untuk tumbuhan dan satwa adalah dengan cara pendekatan (UNCED, 1992), ada dua yaitu: (1) Konservasi In-situ, yaitu konservasi kenakearagaman di habitat asli nya, bisa dengan penetapan Kawasan yang dilindungi seperti Suaka Marga Satwa, Taman Nasional, dan Kawasan dilindungi lainnya. Pendekatan ini dilakukan di tempat asalnya untuk menjaga keanekaragaman (Dudley, et al., 2005). Sementara (2) Konservasi exsitu: yaitu konservasi keanekaragaman bukan di daerah aslinya, seperti di penangkaran atau kebun binatang. Pendekatan ini dilakukan untuk perlindungan satwa yang dilindungi untuk menghidaridari ancaman kepunahan (Cohen, et al., 1991).

Pendidikan konservasi Badak Sumatra dan Badak Jawa yang telah dilakukan menjadi hal penting untuk diketahui. Badak Sumatera (Dicerorhinus sumatrensis, Gloger 1841) merupakan salah satu spesies mamalia besar yang paling terancam punah karena hilanganya habitat, fragmentasi, dan perburu an liar sehingga populasi spesies ini menurun secara drastis. Menurut Brandt, et al (2019), bahwa penyebaran luas Badak Sumatera hingga di Asia Tenggara, saat ini diperkirakan tinggal sekitar 30 individu di Sumatera dan Kalimantan. Distribusi Badak Sumatera di Sumatera terdapat di Taman Nasional Gunung Leuser Taman Nasional Bukit Barisan Selatan, dan Taman Nasional Way Kambas (Zein, et al 2019), sedangkan di Kalimantan sebarannya di wilayah pesisir Sarawak Utara dan Selatan, Semenanjung Sangkulirang (Kalimantan Timur), Kalimantan Tengah antara Banjarmasin dan Kotawaringin, dan Kalimantan Barat di utara Sungai Kapuas. Namun sampai sekitar tahun 1940, Badak Sumatera menghilang dari sebagian besar daerah dataran rendah barat, tengah, selatan, dan timur Kalimantan (Brandt, et al 2019). Secara fisik Badak Sumatra dapat dilihat pada Gambar 1.

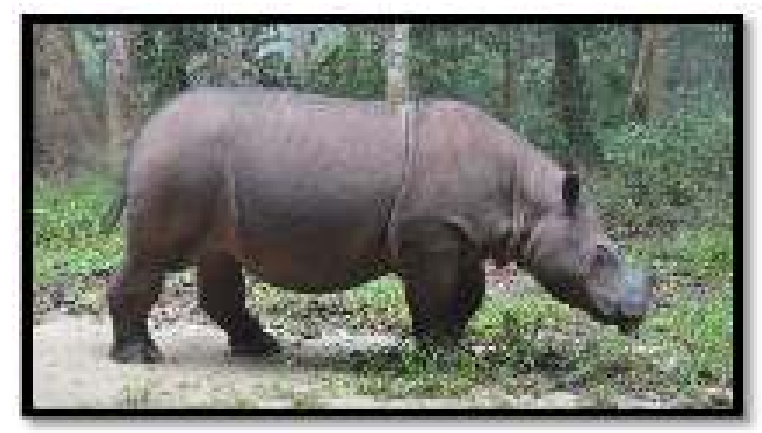

Gambar 1. Penampakan fisik badak Sumatra (Alawiah, 2018)

Demikian pula Badak Jawa (Rhinoceros sondaicus, Desmarest 1822) merupakan spesies paling langka diantara lima spesies badak yang ada di dunia, menurut Rahmat, et al (2008), menyebutkan bahwa spesies tersebut dapat dikategorikan sebagai endangered atau terancam dalam daftar Red List Data Book yang dikeluarkan oleh International Union for Conservation of Nature and Natural Resources (IUCN). Sementara 
berdasarkan Convention on International Trade in Endangered Spesies of Wild Fauna and Flora (CITES) pada tahun 1978 dikategorikan sebagai jenis yang jumlahnya sangat sedikit di alam dan dikhawatirkan akan punah. Hal demikian badak jawa mendapat prioritas utama untuk diselamatkan dari ancaman kepunahan. Selain itu, badak jawa juga terdaftar dalam apendiks I. Di Indonesia, badak jawa hanya terdapat di Taman Nasional Ujung Kulon (TNUK) dengan populasi relatif kecil, yaitu sekitar 59-69 ekor (TNUK 2017). Secara fisik Badak Jawa dapat dilihat pada Gambar 2.

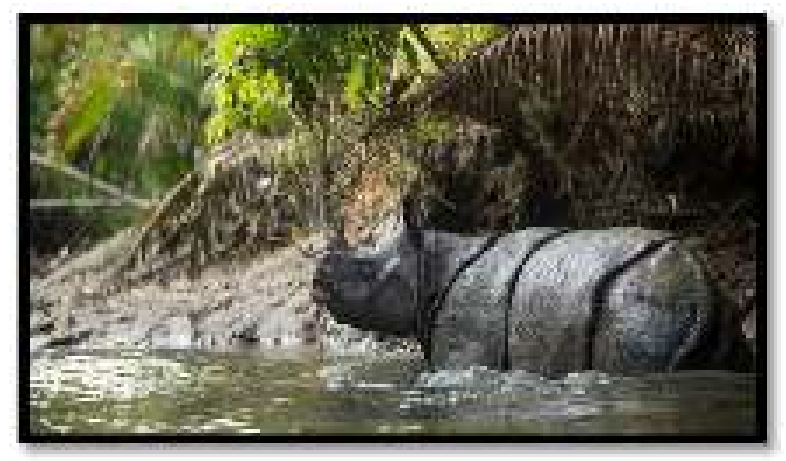

Gambar 2. Penampakan fisik badak Jawa (BTNUK, 2017)

\section{B. Hasil Pre-test dan Post-test Kegiatan}

Evaluasi pre dan post-test kegiatan Pendidikan konservasi ini dilakukan dengan cara membandingkan kecenderungan jawaban yang benar dari para peserta pengabdian. Pre-test yang dibagikan melalui Google Form dibagikan pada saat sebelum pemnyampaian materi, dengan tujuan untuk mengetahui pemahaman awal. Sedangkan pertanyaan post-test diberikan pada akhir acara sebetelah penyampaian materi oleh narasumber dan juga diskusi tanya-jawab antara peserta dan narasumber. Jumlah soal yang diberikan pada pretest dan post-tes sejumlah 10 soal. Peserta yang menjawab pertanyaan pre-test sebanyak 190 peserta. Sedangkan peserta yang menjawab untuk post-test adalah sebanyak 203 peserta. Sebagian besar peserta adalah Peserta Didik SMK Negeri 3 Pandeglang Provinsi Banten. Hal ini karena tujuan kegiatan diarakan kepada Didik SMK Negeri 3 Pandeglang Provinsi Banten pada Bidang Keahlian Kehutanan. Sementara untuk hasil persentasi nilai rataan dari setiap soal baik pre-test maupun post-test dapat dilihat pada Gambar 3.

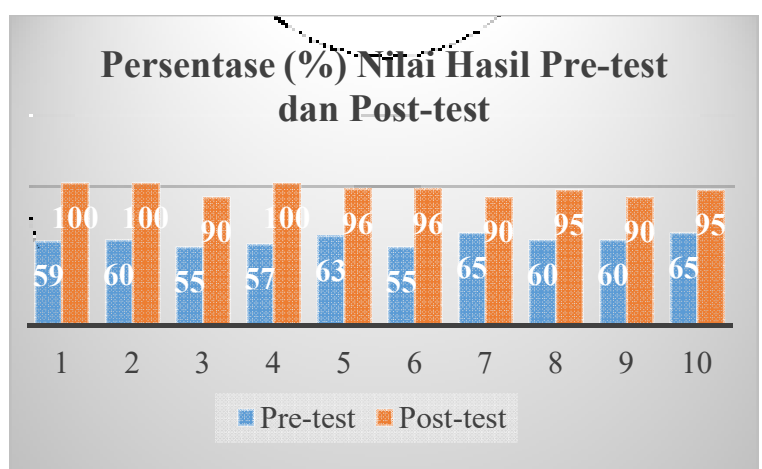

Gambar 3. Persentase nilai hasil pre-test dan posttest (Sumber : Hasil Pengolahan Data)

Berdasarkan Gambar 3 diatas, dijelaskan bahwa perhitungan keefektifan pemberian materi, dilakukan dengan membandingkan tingkat nilai rataan dari jawaban peserta sebelum dan sesudah pemberian materi tersebut. Dari 10 soal yang diberikan, sebelum dilakukan pemberian materi, rata-rata peserta mampu menjawab soal dengan benar antara 50-65\%, sementara setelah dilakukan pemberian materi peserta mampu menjawab soal dengan benar antara 90-100 \%. Hal ini menunjukkan pentingnya pengetahuan dalam memahami kegiatan pendidikan konservasi tersebut tercapai. Dengan demikian pentingya melakukan kegiatan pendidikan konservasi Badak Sumatra dan Badak Jawa yang telah dilakukan yang tepat semakin dipahami oleh Peserta Didik SMKN 3 Pandeglang. Hal ini terlihat dari nilai rata-rata hasil penilaian baik pre-test maupun post-test yang dikerjakan oleh Peserta Didik SMKN 3 Pandeglang sebelum dan setelah materi diberikan. Peningkatan pengetahuan Peserta Didik SMKN 3 Pandeglang terkait konservasi Badak Sumatra dan Badak Jawa dapat dilihat pada Gambar 4.

\section{Nilai Rataan Hasil Penilaian}

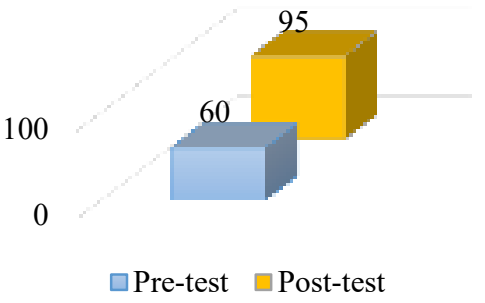

Gambar 4. Nilai rataan hasil penilaian pre-test dan post-test 
Berdasarkan pada Gambar 4 diatas, telah dijelaskan bahwa nilai rataan sebelum materi dimulai (pre-test) sebesar 60 dari 100, sedangkan setelah materi dilaksanakan nilai post-testnya sebesar 95 dari 100. Hal demikian evaluasi pre dan post-test dilakukan dengan cara membandingkan kecendrungan kemampuan dalam menangkap materi dari kegiatan pengabdian kepada masyarakat dalam pendidikan konservasi Badak Sumatra dan Badak Jawa baik sebelum dan sesudah materi dari para peserta pengabdian. Pre-test yang dibagikan melalui Google Form dibagikan pada saat sebelum pemnyampaian materi, dengan tujuan untuk mengetahui pemahaman awal. Sedangkan pertanyaan post-test diberikan pada akhir acara setelah penyampaian materi oleh narasumber dan juga diskusi tanya-jawab antara peserta dan narasumber. Peningkatan pemahaman peserta naik dengan persentase kenaikan pengetahuan peserta dari hasil pre-test dan post-test sebesar 35\%. Presentase kenaikan dinilai sangat baik, meskipun tidak mencapai nilai 100. Hal ini dikarenakan adanya semangat yang tinggi dari peserta dalam mengikuti kegiatan dan tujuan pendidikan konservasi untuk meningkatkan pemahaman tentang konsep konservasi dan pentingnya konservasi Badak Sumatra dan Badak Jawa tercapai.

Pendididikan konservasi sumberdaya hutan adalah bagian konsep penting dari kegiatan pengabdian masyarakat dalam pengupayaan perlindungan, pemanfaatan dan pengawetan sumberdaya hutan pada generasi sekarang ke generasi ke masa yang akan datang. Kegiatan pendidikan konservasi juga merupakan bentuk aktivitas dalam mensosialisasikan konsep konservasi ke masyarakat umum guna menyadarkan akan pentingnya pelestarian, pengawetan dan pemanfaat sumber daya secara lestari. Edukasi konservasi kepada Peserta Didik SMK Negeri 3 Pandeglang Provinsi Banten merupakan bagian dari salah satu cara dalam memperkenalkan konsep konservasi konservasi dan pentingnya konservasi Badak Sumatra dan Badak Jawa. Hal demikian dilakukan karena target dari pendidikan konservasi adalah generasi muda sebagai penerus bangsa nantinya.

Universitas Lampung melalui Tim Konservasi Universitas Lampung, Magister Kehutanan Fakultas Pertanian Universitas Lampung, Peer Group KSDH, Jurusan Kehutanan Fakultas Pertanian Universitas Lampung,
Himasylva, Persatuan Sarjana Kehutanan Indonesia DPD Lampung, Balai Taman Nasional Ujung Kulon (TNUK) dan SMK Negeri 3 Pandeglang Provinsi Banten telah melaksanakan Pendidikan Konservasi dalam Kegiatan Pengabdian Masyarakat yang telah dilakukan untuk pelestarian konservasi Badak Sumatra dan Badak Jawa yang dilindungi saat ini.

\section{Kesimpulan}

Pendididikan Konservasi adalah konsep yang penting dari kegiatan pengabdian masyarakat untuk pengupayaan perlindungan, pemanfaatan dan pengawetan sumberdaya hutan dalam kepentingan generasi ke generasi berikutnya. Kegiatan Pengabdian Kepada Masyarakat Online Tentang Pendidikan Konservasi Badak Sumatra Dan Jawa Pada Peserta Didik Sekolah Menengah Kejuruan Negeri 3 Pandeglang, Provinsi Banten telah dilakukan secara daring Zoom dan Youtube, oleh Tim Konservasi Universitas Lampung, Magister Kehutanan Fakultas Pertanian Universitas Lampung, Peer Group KSDH, Jurusan Kehutanan Fakultas Pertanian Universitas Lampung, Himasylva, Persatuan Sarjana Kehutanan Indonesia DPD Lampung, Balai Taman Nasional Ujung Kulon (TNUK) dan SMK Negeri 3 Pandeglang Provinsi Banten. Peserta yang mengikuti pemaparan adalah siswa-siswi kehutanan SMKN 3 Pandeglang, para guru dan forum MGMP Kehutanan Seluruh Indonesia, mahasiswa S1, S2 Kehutanan Unila, dan instansi terkait didalamnya. Peningkatan pemahaman peserta naik sebesar 35\%. Presentase kenaikan dinilai sangat baik. Hal ini karena semangat yang tinggi dari peserta dalam mengikuti kegiatan pendidikan konservasi dalam meningkatkan pemahaman tentang konsep konservasi dan pentingnya konservasi Badak Sumatra dan Badak Jawa pun dinilai tercapai.

\section{Daftar Pustaka}

Awaliah, A. T. S. 2018. Perilaku makan dan studi pakan badak sumatera (Dicherorhinus sumatrensis) di suaka rhino sumatera taman nasional way kambas. Skripsi. Bandar Lampung : Universitas Lampung.

Brandt, JR., PJ. van Coeverden de Groot, KE. Witt, PK. Engelbrektsson, KM. Helgen, RS. Malhi, OA. Ryder \& AL. Roca. 2018. Genetic structure and diversity among historic and modern population of the Sumatran Rhinoceros (Dicerorhinus sumatrensis). Journal Heredity 109(5): 553- 565. 
Cohen, J. I., Williams, J. T., Plucknett, D. L., dan Shands, H. (1991). Ex situ conservation of plant genetic resources: Global development and environmental concerns. Science, 253(5022), 866-872. doi:10.1126/science.253.5022.866.

Collin, G. dan Dixon, H. 1991. Integrated Learning. Australia: Bookshelf Publishing.

Dudley, N., Mulongoy, K. J., Cohen, S., Stolton, S., Barber, C. V., dan Gidda, S. B. (2005). Towards effective protected area systems. An action guide to implement the convention on biological diversity programme of work on protected areas. Quebec, Canada: Secretariat of the Convention on Biological Diversity, Montreal.

Mongabay Indonesia. 2020. Penting bagi Dunia: Berikut 10 Informasi tentang Hutan Hujan Tropis. [online].

$$
\text { Link }
$$
https://www.mongabay.co.id/2020/06/22/penting -bagi-dunia-berikut-10-informasi-tentang-hutanhujan-tropis/. Diakses pada tanggal 01 Juni 2021.

Purmadi, R. M., Santika, D. M. J., Wulandari, S. A. 2020. Pentingnya Pendidikan Konservasi Untuk Menjaga Lingkungan Hidup (Studi Kasus di Desa Cidahu, Kabupaten Kuningan). Jurnal Pusat Inovasi Masyarakat Vol. 2 (4) : 602-606.

Rahmat, U. M., Santosa, Y., dan Kartono, A. P. 2008. Analisis Preferensi Habitat Badak Jawa (Rhinoceros sondaicus, Desmarest 1822) di Taman Nasional Ujung Kulon. JMHT Vol. XIV, (3): 115-124.

Vol 5 No 3 November 2021
Rohman, N. A., dan Wulandari, C. 2021. Manfaat 'Ethnoforestry' di Era Pandemi Covid-19. Diakses pada tanggal 01 Juli 2021 dengan alamat https://hijauku.com/2021/04/12/manfaatethnoforestry-di-era-pandemi-covid-19/.

Taman Nasional Ujung Kulon (TNUK). 2017. Laporan Sensus Badak Jawa (Rhinoceros sondaicus. Desmarest, 1822) di Taman Nasional Ujung Kulon, Labuan. Tidak dipublikasikan.

UNCED. 1992. Convention on Biological Diversity. Geneva: United Nations Conference on Environmant and Development.

Undang Undang Republik Indonesia no 41 tahun 1999 Tentang Kehutanan. 1999.

Undang-Undang Nomor 5 tahun 1990 tentang Konservasi Sumberdaya Hutan. 1990.

Undang-Undang Republik Indonesia Nomor 12 Tahun 2012 Tentang Pendidikan Tinggi. 2012. Retrieved 4 6, 2017, from Portal Mahkamah Konstitusi: https://portal.mahkamahkonstitusi.go.id/eLaw/m g58ufsc89hrsg/lf32ffaa 33 555e001038d1e0cda7b281849acef2d.pdf.

WWF. 2020. Discover tropical rainforests. [online]. Link:

https://wwf.panda.org/our_work/forests/importan ce_forests/tropical_rainforest/ . Diakses pada tanggal 01 Juni $20 \overline{2} 1$.

Zein, M. S. A., Fitriana, Y. S., Kurniawan, Y., Chaerani, K., dan Sirupang, M. 2019. Kajian Genetika untuk Konservasi Badak Sumatera (Dicerorhinus sumatrensis Gloger, 1841). 